\title{
PERIKLANAN DALAM PERSPEKTIF ETIKA ISLAM
}

\section{Mustafa}

Email: mustafa@uin-suska.ac.id

Prodi Ilmu Komunikasi Fakultas Dakwah dan Komunikasi Universitas Islam Negeri Sultan Syarif Kasim Riau.

\begin{abstract}
Advertising is the main element of a company's promotion tool. Most companies spend a lot of money on advertising around 25\% of the total budget. Advertising is very important to increase an organization's revenue. But recently, some advertisements made false promises to attract new customers to buy products that are strictly prohibited in Islam. In this paper, we try to establish several dimensions of advertising supported by Islam. There should be no practice of fraud, fraud, misrepresentation, coercion, and injustice in measurement; and there shouldn't be anything unfair. In this article the author tries to find out the Islamic point of view of advertising where the public will find advertisements working as they should.
\end{abstract}

Keyword : Islam, Advertising, Communication

\section{Pendahuluan}

Periklanan adalah fenomena yang kompleks karena begitu banyak pengiklan yang berbeda mencoba menjangkau begitu banyak jenis audiens yang berbeda dan berisi tiga tujuan yang pada dasarnya untuk memberi informasi, membujuk dan mengingatkan. Model konseptual tradisional untuk membuat iklan atau pesan komunikasi pemasaran adalah model AIDA; dapatkan perhatian, pertahankan minat, bangkitkan

keinginan dan dapatkan tindakan.

John Caples, penulis salinan terhebat memperluas konsep komunikasi pemasaran tradisional dengan prinsip-prinsip berikut ini, yaitu, mendapatkan,mempertahankan perhatian, menciptakan keinginan, membuatnya dapat dipercaya, membuktikannya sebagai tawarmenawar, membuatnya mudah untuk membeli dan memberikan alasan untuk

Mustafa I Persepsi Demokrasi Indonesia di Arab Saudi Analisis Framming Berita Pemilihan Presiden Indonesia 2019 di Situs Arab News.com 
beli sekarang. Periklanan juga dapat dijelaskan dalam hal empat peran yang dimainkannya dalam bisnis dan di masyarakat:

\section{Peran pemasaran}

Peran pemasaran periklanan adalah untuk membawa pesan persuasif kepada pelanggan aktual dan potensial. Peran komunikasi: Iklan adalah bentuk komunikasi massa. Ini mentransmisikan berbagai jenis informasi pasar kepada pembeli dan penjual di pasar. Beriklan baik menginformasikan dan mengubah produk dengan menciptakan gambar yang melampaui fakta langsung. Peran ekonomi: ada dua sudut pandang tentang bagaimana iklan memengaruhi suatu ekonomi.

Pada awalnya, iklan sangat persuasif sehingga mengurangi kemungkinan bahwa konsumen akan beralih ke produk alternatif, terlepas dari harga yang dibebankan. Pendekatan kedua memandang iklan sebagai kendaraan untuk membantu konsumen menilai nilai, melalui harga serta elemen- elemen lain seperti kualitas, lokasi, dan reputasi.

\section{Peran sosial}

iklan juga memiliki sejumlah peran sosial. Ini memberi tahu kami tentang produk-produk baru dan yang ditingkatkan dan membantu kami membandingkan produk dan fitur serta membuat keputusan konsumen yang terinformasi kapan saja iklan yang menjadi perhatian Islam.

Dikatakan dalam Alquran, "Allah telah melegalkan perdagangan dan perdagangan dan telah melarang minat" (Al-Baqarah)

Nabi Muhammad SAW berkata, "Sembilan persepuluh dari penghasilan terletak pada perdagangan dan perdagangan."

Islam adalah kode kehidupan yang lengkap. Ia memiliki arahan sendiri untuk membuat sebuah negara kuat secara politik, sehat secara sosial, tidak memiliki budaya dan makmur secara ekonomi.

Sejak awal Islam, para pengikut Nabi Muhammad SAW didorong dalam perdagangan dan perdagangan yang

Mustafa I Persepsi Demokrasi Indonesia di Arab Saudi Analisis Framming Berita Pemilihan Presiden Indonesia 2019 di Situs Arab News.com 
jujur. Islam mengatakan bahwa perdagangan tidak hanya berorientasi pada keuntungan, tetapi melalui perdagangan orang harus melayani orang yang membutuhkan dan oleh karena itu, Allah SWT. Ini berarti perdagangan harus memiliki dua tujuan untuk menghasilkan laba yang wajar untuk mempertahankan keluarga dan untuk memasok kebutuhan kepada orang-orang dalam pertukaran uang dan dengan demikian untuk memenuhi kebutuhan mereka.

Perdagangan dan bisnis, dari sudut pandang Islam, harus dilakukan untuk kesejahteraan umat manusia. Karena, iklan adalah bagian dari bisnis yang menyediakan informasi tentang produk atau layanan maka itu juga diizinkan dalam Islam. Pada tahap utama Islam, iklan pada dasarnya adalah kata-kata komunikasi mulut. Orang biasanya mengunjungi berbagai kota dan ketika mereka berpengalaman dengan beberapa jenis barang / jasa; mereka menyebarkan informasi ke tetangga setelah kembali ke tempat asal.
Di dunia saat ini, ditemukan iklan dalam berbagai cara dengan menggunakan beberapa media, alat, dan teknik. Media dapat berupa radio, televisi, koran, majalah, dan internet. Alat bisa berupa mesin dan orang, sedangkan teknik bisa berupa berbagai jenis pesan atau ekspresi. Oleh karena itu, strategi periklanan memainkan peran penting untuk mendapatkan pendapatan yang sehat, menarik pelanggan dan sebagai kompetensi khas beberapa organisasi. Beberapa organisasi juga percaya pada slogan "Iklan untuk ekspansi". Dalam makalah ini, kami mencoba menentukan serangkaian dimensi iklan yang didukung oleh Islam dan juga mencoba menilai beberapa iklan populer dari beberapa organisasi yang diakui dengan bantuan pandangan dan konsep Islam.

\section{Kritik pada Iklan oleh Cendekiawan Muslim}

Meskipun kritik semacam itu sangat baru dalam sejarah sastra, namun cukup relevan untuk dimasukkan dalam studi tentang sifat Islam. Hanya dalam

Mustafa I Persepsi Demokrasi Indonesia di Arab Saudi Analisis Framming Berita Pemilihan Presiden Indonesia 2019 
terang kritik ini bahwa versi iklan Islam dapat diusulkan.

Iklan kontemporer dinilai telah menjadi menjadi seni penipuan dan manipulasi; karena sekarang iklan bermaksud menipu orang, kata Saeed et al. (2011). Hal Itu dapat dilihat pada iklan yang sengaja melebih-lebihkan sajian fitur atau kinerja produk, memikat pembeli impulsif atau melalui kata-kata yang menarik, demonstrasi bertahap, kontes kecurangan, dan menghilangkan informasi produk tertentu (Abdullah \& Ismail, 2011), mengeksploitasi ambiguitas, atau menyembunyikan fakta yang tidak menarik untuk produk mereka (Saeed et al., 2011; Al-Buraey, 2004).

Di tengah kekacauan iklan, munculnya telekomunikasi, dan berbagai pilihan bagi pelanggan, para pengiklan untuk memenangkan pelanggan terkadang membuat janji yang sulit dipenuhi. Adalah masuk akal untuk berpikir bahwa di lain waktu mereka membuat janji-janji seperti itu dengan sengaja, mengkritik Alserhan (2011).
Iklan kontemporer juga mendapat kecaman karena menggambarkan perempuan; apakah mereka berpakaian provokatif, atau stereotip (Saeed et al., 2001; Rice \& Al-Mossawi 2002; AlBuraey, 2004; Spence \& Heekeren, 2005; Alserhan, 2011), atau ketika kehadiran mereka tidak relevan (Haque et al., 2011). Iklan kontroversial semacam itu mungkin menjadi bumerang (Haque et al., 2011). Ada banyak insiden ketika perempuan terpapar sebagai objek seksual belaka dalam iklan telah menerima reaksi sosial dan hukum (Alserhan, 2011).

Al-Buraey (2004) mengatakan bahwa iklan kontemporer sambil mengeksploitasi selera manusia untuk kesombongan, seks, kesenangan, dan kenyamanan, mendefinisikan kembali kebahagiaan dan kepuasan dalam istilah materialistis murni. Anwar dan Saeed (1996) menyesalkan bahwa iklan saat ini biasanya memenuhi kebutuhan psikologis seseorang akan status, kekuatan, dan keintiman seksual dengan menargetkan emosi, keinginan, ketakutan, dan kecemasan mereka. Al-

Mustafa I Persepsi Demokrasi Indonesia di Arab Saudi Analisis Framming Berita Pemilihan Presiden Indonesia 2019 di Situs Arab News.com 
Buraey (2004), Spence \& Heekeren (2005), dan Saeed et al. (2011) mengkritik periklanan dengan menulis hal yang sama dengan yang dibujuknya dengan menarik sentimen seseorang sementara sebaliknya, iklan harus menarik bagi intelek. Penargetan seperti itu membuat audiens menghabiskan waktu yang tidak perlu dan berkontribusi pada pikiran yang tumpul, kata sumber yang sama.

\section{Kritik pada Iklan oleh Sarjana Non-} Muslim

Kritik pada iklan tidak akan lengkap tanpa akun apa yang dikatakan non-Muslim. Iklan dikenakan biaya untuk "berbagai dosa", katakan Eze \& Lee (2012: 94). Demikian pula, Fullerton et al. (2013: 33) melaporkan bahwa jajak pendapat Gallup untuk mengukur etika profesional sering menilai iklan paling rendah, oleh karena itu frasa umum lahir bahwa "etika periklanan adalah sebuah oxymoron".

Demikian pula, Schlegelmilch (2001) melaporkan survei di seluruh dunia di mana: $72 \%$ percaya bahwa klaim kesehatan dalam iklan sengaja dibesar-besarkan, 70\% percaya bahwa iklan mencuci otak anak-anak, 61\% percaya bahwa ukuran / jumlah / isi aktual di dalam kemasan lebih rendah dibandingkan dengan yang ditunjukkan dalam iklan.

Mayoritas kritik pada iklan adalah efek buruk sosialnya. Iklan dikatakan mendorong materialisme (Arens et al., 2013). Lebih lanjut, itu secara salah mempromosikan pengeluaran yang tidak perlu (Fullerton et al., 2013). Iklan menciptakan nilai-nilai yang salah dalam masyarakat (Kumar, 2012) dalam bentuk polusi intelektual dan moral (Eze \& Lee, 2012). Andrews (1989) menyatakan bahwa melalui upaya terencana atas nama perusahaanperusahaan kuat, iklan menarik ketakutan, rasa bersalah, kecemasan,inferioritas,ketidakbahagiaa n, dan ketidakmampuan, sehingga memangsa jiwa konsumen yang tidak curiga. Dalam hal ini, satu kontroversi yang sangat mendesak adalah tentang tubuh dan citra diri seseorang yang membuat seseorang mengambil langkah

Mustafa I Persepsi Demokrasi Indonesia di Arab Saudi Analisis Framming Berita Pemilihan Presiden Indonesia 2019 
ekstrim untuk meniru para selebritas (Wells et al., 2008; Clow \& Baack, 2012; Arens et al., 2013). Itu bahkan menyebabkan lebih banyak depresi meskipun menghabiskan banyak uang ketika keinginan mereka untuk terlihat seperti selebriti tidak terpenuhi (Kumar, 2012).

Periklanan juga dikritik karena efek buruk tertentu lainnya, seperti: itu memperkuat perilaku tertentu untuk menjadi norma (Spence \& Heekeren, 2005; Wells et al., 2008); itu mengalahkan dan mengendalikan media (Greyser, 1972); itu menipu dan menyesatkan (Kottman, 1969; Andrews, 1989; Pollay \& Mittal, 1993; Pratt \& James, 1994; Schlegelmilch, 2001; Wells et al., 2008; Shimp, 2010; Eze \& Lee, 2012; Kumar, 2012; Arens et al., 2013); mempromosikan dan menjual produk yang kontroversial, tidak sehat, atau bahkan berbahaya (Clow \& Baack, 2012; Kumar, 2012; Arens et al., 2013).

\section{Etika Islam}

Etika mengatur semua aspek kehidupan dalam Islam, bisnis dan pribadi (Beekun, 2003). Ini adalah kondisi untuk kesuksesan abadi (falāh) dan tanpa konteks apa pun, seperti yang dikatakan Allah SWT dalam Al-Quran (3: 104) bahwa orang-orang sukses adalah mereka yang "mengundang semua yang baik (khayr), memerintahkan apa benar (ma'rūf) dan melarang apa yang salah (munkar)".

Dari sudut pandang Islam, etikaetika ini berasal dari cinta kepada Tuhan, tulis Riaz (1992). Cabang langsung dari cinta tersebut adalah cinta untuk diri sendiri dan cinta untuk manusia lain. Yang pertama menyiratkan bahwa seseorang harus memperluas semua upaya yang mungkin "untuk membuat diri sendiri terdengar secara fisik, spiritual, moral, intelektual, dan ekonomi" (Riaz, 1992: 80).

Cinta untuk sesama makhluk meminta perilaku baik seperti "simpati, belas kasihan, kebaikan, rasa hormat, kemurahan hati" (Riaz, 1992: 80) serta berbuat baik kepada orang lain dan menghindari bahaya bagi mereka dan kepentingan sah mereka.

Mustafa I Persepsi Demokrasi Indonesia di Arab Saudi Analisis Framming Berita Pemilihan Presiden Indonesia 2019 
Islam membimbing pengikutnya dalam semua aspek kehidupan, termasuk kegiatan komersial dan ekonomi. Panduan ini berakar pada AlQuran dan Sunnah (tindakan / ucapan Nabi Muhammad). Ini menuntun pengikutnya untuk mematuhi prinsipprinsip keadilan dan keadilan ketika memperluas upaya untuk meningkatkan standar hidup.

Keunikan Islam disoroti di sini karena tidak memisahkan aspek kehidupan duniawi dan spiritual (Haque et al., 2011). Itu membimbing, dan meminta para pengikutnya untuk mengikutinya, dalam semua aspek kehidupan, sambil mempertimbangkan ajarannya sebagai tindakan ibadah bersama dengan ibadah wajib. Kegiatan yang sama dianggap bertanggung jawab di depan Allah SWT. Prinsip dasar inilah yang memandu semua kegiatan komersial pedagang Muslim, termasuk pemasar, Abdullah \& Ahmad (2010).

Pemasaran Islam secara langsung berasal dari filosofi ini dan karena itu menghasilkan buah yang berbeda dari mitra kontemporernya. Etika pemasaran Islam berbeda dari rekan sekuler mereka pada dimensi berikut, seperti yang diberikan oleh Saeed et al. (2001)

1. Karena mereka tidak relatif, mereka tidak tunduk pada interpretasi pribadi seseorang dan dengandemikian mengesampingkan keinginan dan keinginan pribadi seseorang.

2. Mereka bersifat absolut dan bertujuan untuk tujuan yang lebih tinggi.

3. Mereka menekankan pemaksimalan nilai, berbeda dengan tujuan sekuler dari pemaksimalan laba, sehingga melayani manfaat bagi seluruh masyarakat.

Konsep-konsep ini adalah penggambaran epik keadilan dan permainan yang adil, yang menahan seseorang dari praktik yang tidak etis. Hassan et al. (2008) percaya prinsipprinsip tersebut memiliki daya tembus yang dalam di hati nurani manusia yang mempengaruhi perilaku mereka. 
Dalam kerangka Islam, tanggung jawab seorang pemasar dibagi menjadi empat kategori: pertama adalah tanggung jawab utama terhadap Tuhan yang mengembalikan semua perbuatan. Kedua adalah terhadap masyarakat dan sesama manusia, yang dipandang terhormat. Ketiga adalah menuju dirinya sendiri, sebagai manusia dan pemasar. Dan terakhir adalah menuju lingkungan yang hanya sementara hak asuh yang diberikan oleh Tuhan (Hassan et al., 2008, Abuznaid, 2012). Selain itu, setiap aktivitas komersial dalam Islam dipandu oleh dua prinsip: tunduk pada kehendak Allah SWT; dan menunjukkan empati dan rahmat kepada ciptaan-Nya (SWT) sehingga mereka tidak dirugikan dan praktik buruk dapat diatasi.

\section{Aturan umum untuk promosi Islam}

Sehubungan dengan iklan ada perbedaan besar di seluruh dunia dalam hal apa yang berbahaya bagi masyarakat (Schlegelmilch, 2001). Bahkan pada konsep yang paling mendasar ada pendapat yang berbeda, ambil puffer misalnya, atau ketelanjangan dalam hal ini. Meskipun ilegal di banyak negara, AS menyetujui hal itu (Schlegelmilch, 2001; Arens et al., 2013).

Hal yang sama berlaku untuk penggambaran seks dalam iklan (Clow \& Baack, 2012), yang sepenuhnya diizinkan di Prancis selama hal itu dibenarkan. Perbedaan pendapat ini dapat dihapuskan jika hanya sumber referensi tunggal diambil. Profesor Rodney Wilson (kata pengantar dalam Hasanuzzaman, 2003) percaya bahwa sumber tunggal semacam itu tersedia bagi umat Islam, dalam bentuk kitab suci mereka.

Berasal dari buku yang sama dan tindakan Nabi Muhammad SAWW, para ulama telah mengekstraksi kerangka etisnya

promosi. Alserhan (2011) memberikan beberapa aturan untuk promosi, tetapi yang relevan dengan periklanan disebutkan di bawah ini:

1. tidak mengeksploitasi naluri dasar konsumen dan harus

Mustafa I Persepsi Demokrasi Indonesia di Arab Saudi Analisis Framming Berita Pemilihan Presiden Indonesia 2019 
menghindari hasrat yang tidak pernah terpenuhi.

2. harus didasarkan pada kebenaran dan pengungkapan lengkap semua atribut produk.

3. Produk tidak boleh haram dan berbahaya.

4. Harus menganjurkan konsumsi sebagai bentuk ibadah dan mempromosikan moderasi dalam hal yang sama.

\section{Pedoman khusus untuk iklan Islami}

Aturan yang disebutkan di atas dapat diterjemahkan ke dalam pedoman untuk kegiatan promosi bisnis. Untuk iklan, aturan-aturan ini menentukan bahwa seharusnya:

1. Tidak menyebarkan praktik boros atau pengeluaran berlebihan (Haque et al., 2011). Prinsip ini mencakup kritik bahwa penggemar iklan materialisme dan pengeluaran berlebihan, seperti dibahas di atas. Selain itu, prinsip ini juga relevan dengan gagasan bahwa periklanan membuat perilaku menyimpang menjadi norma (Spence \& Heekeren, 2005; Wells et al., 2008). Ini juga mencakup kritik pada iklan untuk anak-anak. Karena periklanan disalahkan karena menciptakan kebiasaan yang tidak sehat dan karakter anak yang tidak diinginkan, prinsip periklanan Islam ini dapat menjadi dasar dalam membatasi masalah ini.

2. Tidak menggunakan wanita atau menunjukkan bagian tubuh manusia dengan cara sensual untuk menunjukkan daya tarik seksual, untuk memikat penonton (Behravan et al., 2012). Ini adalah salah satu masalah etika terbesar dalam periklanan

3. Tidak menggambarkan selebriti atau model menarik seolah-olah mereka menggunakan produk padahal sebenarnya tidak (Abuznaid, 2012). Penggunaan model yang menarik juga mencakup penggunaan fantasi dalam iklan yang tidak diizinkan dalam iklan Islami (Alserhan, 
2011; Bari \& Abbas, 2011). Iklan juga banyak dikritik karena penggunaan selebriti, seperti dibahas di atas (Wells et al., 2008; Clow \& Baack, 2012; Arens et al., 2013), terutama ketika khalayak umum tidak berhasil menyalinnya (Kumar 2012) .

4. Jujur dan bebas dari penipuan apa pun, atau menyembunyikan fakta apa pun (Damirchi \& Shafai, 2011). Ini juga mencakup konsep keadilan dalam periklanan, yang berarti mengungkapkan kesalahan dan cacat.

5. Tidak memiliki pernyataan yang keliru (termasuk penelitian palsu), tuduhan yang tidak terbukti, ramuan, dan testimoni make-up (Abuznaid, 2012). Berlebihan juga merupakan bagian yang sama.

6. Tidak mengandung janji palsu yang tidak dimaksudkan untuk disampaikan (Haque et al. (2011) istilah itu pemenuhan janji.
7. Tidak memikat orang untuk percaya, ketika tidak ada, hadiah atau diskon (Al-Buraey, 2004;

Tiga prinsip terakhir adalah sebagai tanggapan atas penipuan umum yang ada dalam iklan kontemporer. Ini mungkin kritik paling umum pada iklan yang menyesatkan.

\section{Simpulan}

Pemasaran Islam tidak hanya "daging dan uang" (Wilson, 2012). Ini berisi panduan lengkap dan jawaban yang memuaskan untuk semua pertanyaan yang berkaitan dengan praktik periklanan yang tidak etis. Itu berasal dari filosofi yang berbeda dan memiliki buah yang jauh jangkauannya. Al Fārūqī (2000: 41) menulis tentang ini kesempurnaan dengan cara yang indah: "kewajaran Islam terdiri dari daya tariknya pada pikiran pada kondisi kritisnya.

Islam tidak takut pada bukti yang berlawanan juga tidak beroperasi secara rahasia, menggunakan daya tariknya terhadap perasaan, sebagian 'keraguan' 
dan ketidakpastian 'batin, beberapa angan-angan atau keinginan untuk realitas menjadi lain daripada yang sebenarnya. Klaim Islam bersifat publik. Itu ditujukan kepada akal, berusaha meyakinkannya akan kebenaran, daripada membanjiri dengan yang tidak bisa dipahami ...". Sekarang tergantung pada pemasar Muslim untuk secara khusus mengerjakan prinsip-prinsip ini dan secara praktis membuktikan keberanian iklan Islam.

Artikel ini ingin memberi pengaruh bagi pengiklan, terutama kaum muslim. Iklan yang didasarkan pada prinsip-prinsip semacam itu berpotensi mengekang praktik periklanan kontemporer seperti yang disebutkan dalam tulisan ini. Selain itu, universalitas prinsip-prinsip ini membebaskan praktik periklanan dari relativisme etis juga. Jika saja pengiklan dapat diyakinkan akan potensinya, iklan Islam akan memiliki masa depan iklan.

Tapi itu akan menjadi tugas berat. pengiklan kontemporer perlu bukti empiris untuk diyakinkan. Salah satu upaya tersebut akan dilakukan oleh penulis yang sama dalam upaya untuk menemukan sikap konsumen terhadap iklan Islam.

\section{Referensi}

Abdullah, K. (2008). Marketing Mix from an Islamic Perspective. Kuala Lumpur, Malaysia: Pearson Prentice-Hall.

Abdullah, K., \& Ahmad, M. I. (2010). Compliance to Islamic marketing practices among businesses in Malaysia. Journal of Islamic Marketing , 1 (3), 286-297.

Abdullah, K., \& Ismail, Y. (2011). Malaysian Consumers' Experience with Deceptive Marketing Practices of Sellers - An Islamic Perspective.

In O. M. Zain (Ed.), Readings in Marketing: An Islamic Perspective (pp. 247-275). Kuala Lumpur, Malaysia: IIUM Press.

Abuznaid, S. A. (2009). Business ethics in Islam: the glaring gap in practice. Isnternational Journal of Islamic and Middle Eastern Finance and Management, 2 (4), 278-288.

Abuznaid, S. (2012). Islamic Marketing: Addressing the Muslim Market. An-Najah University Journal of Research (Humanities), 26 (6), 1473-1503. 
Al Fārūqī, I. R. (2000). Al Tawhìd: Its Implications for Thought and Life (Vol. Issues in Islamic Thought: 4). Herndon, Virginia, USA: International Institute of Islamic Thought, U.S.A.

Al-Buraey, M. A. (2004). Marketing Mix Management from an Islamic Perspective: Some Insights. Journal of International Marketing and Marketing Research , 29 (31), 123.

Al-Hyari, K., Alnsour, M., Al-Weshah, G., \& Haffar, M. (2010). Religious beliefs and consumer behaviour: from loyalty to boycotts. Journal of Islamic Marketing , 3 (2), 155174.

Alserhan, B. A. (2011). The Principles of Islamic Marketing. Surrey, England: Gower Publishing Limited.

Andrews, J. C. (1989). The Dimensionality of Beliefs toward Advertising in General. Journal of Advertising, 18 (1), 26-35.

Anwar, M., \& Saeed, M. (1996). Promotional Tools of Marketing: An Islamic Perspective. Intellectual Discourse. 4, pp. 15-30. Kuala Lumpur: International Islamic University Malaysia.

Arens, W. F., Weigold, M. F., \& Arens, C. (2013). Contemporary Advertising and Integrated Marketing Communications (14th ed.). New York, NY, US: McGraw-Hill Irwin
Arham, M. (2010). Islamic perspectives on marketing. Journal of Islamic Marketing, 1 (2), 149- 164.

Bari, A., \& Abbas, R. Z. (2011). Advertisement $\mathcal{E}$ Islam: A Muslim World Perspective. Australian Journal of Business and Management Research, 1 (6), 152-157.

Beekun, R. I. (2003). Islamic Business Ethics. New Delhi, India: Goodword Books Pvt. Ltd.

Behravan, N., Jamalzadeh, M., \& Masoudi, R. (2012). A Review Study of Developing an Advertising Strategy for Westerner's Companies among Middle East Countries: the Islamic Perspective. Information Management and Business Review, 4 (3), 107-113.

Clow, K. E., \& Baack, D. (2012). Integrated Advertising, Promotion, and Marketing Communications (5th ed.). England: Pearson Education Limited.

Damirchi, G. V., \& Shafai, J. (2011). A Guideline to Islamic Marketing Mix. Interdisciplinary Journal of Contemporary Research in Business, 3(3), 1339-1347.

Dubinsky, A. J., \& Hensel, P. J. (1984). Marketing Student Attitudes Toward Advertising: Implications for Marketing Education. Journal of Marketing Education . 
Dunn, S. W., \& Barban, A. M. (1982). Advertising: Its Role in Modern Marketing (5th ed.). Japan: HoltSaunders International Editions.

Eze, U. C., \& Lee, C. H. (2012). Consu mers' Atti tude towards Advertising. International Journal of Business and Management, 7 (13), 94-108.

Fullerton, J. A., Kendrick, A., \& McKinnon, L. M. (2013). Advertising Ethics: Student Attitudes and Behavioral Intent. Journalism \& Mass Communication Educator, 68 (1), 33-49.

Hakim, S. A., Bhatti, O. K., \& Al-Jubari, I. (2011). Advertising of Islamic Banking products. Annals of Management Research, 1 (2), 6070.

Haque, A., Ahmed, K., \& Jahan, S. I. (2010). Shariah observation: advertising practices of Bank Muamalat in malaysia. Journal of Islamic Marketing, 1 (1), 70-77

Haque, A., Rahman, S., \& Ahmed, M. I. (2011). Advertising Practices of Islamic Banks in Malaysia: An Empirical Assessment Under Islamic Observation. In O. M. Zain (Ed.), Readings in Marketing: An Islamic Perspective (pp. 277308). Kuala Lumpur, Malaysia: IIUM Press.

Hasanuzzaman, S. M. (2003). Islam and Business Ethics. London, UK:
Institute of Islamic Banking and Insurance.

Hassan, A., Chachi, A., \& Latiff, S. A. (2008). Islamic Marketing Ethics and Its Impact on Customer Satisfaction in the Islamic Banking Industry. Journal of King Abdul Aziz University: Islamic Economics , 21 (1), 23-40.

Kartajaya, H., \& Sula, M. S. (2006). Sharia Marketing: Business Principles Based on Islamic Values. Jakarta, Indonesia: MarkPlus \& Co.

Kottman, E. J. (1969). Truth and the Image of Advertising. Journal of Marketing, 4(1), 64-66.

Kumar, S. (2012). Marketing and Business Ethics. New Delhi, India: Random Publications.

Luqmani, M., Yavas, U., \& Quraeshi, Z. (1987). Advertising in Saudi Arabia: Content and Regulation. International Marketing Review, $6(1), 59-72$.

Md. Ilyas, Q. S. (1992). Dimensions of Muslim Religiosity: Measurement Considerations. In $\mathrm{Z}$.

A. Ansari (Ed.), Quranic Concepts of Human Psyche (Islamization of Knowledge - 11 ed., pp. 99-114). Islamabad, Pakistan: International Institute of Islamic Thought, Islamabad and Institute of Islamic Culture, Lahore. 
Qureshi, Z. A., Luqmani, M., Schlutz, R., \& Zain, O. M. (2011). Conscientious Marketing: Setting Foundations in Making a Difference in People's Lives. In O. M. Zain (Ed.), Readings in Marketing: An Islamic Perspective (pp. 2-29). Kuala Lumpur, Malaysia: IIUM Press.

Rice, G., \& Al-Mossawi, M. (2002). The Implications of Islam for Advertising Messages: The Middle Eastern Context. Journal of Euromarketing , 11 (3), 71-96.

Saeed, M., Ahmed, Z. U., \& Mukhtar, S. M. (2001). International Marketing Ethics from an Islamic Perspective: A Value-Maximization Approach. Journal of Business Ethics , 32, 127-142.

Schlegelmilch, B. (2001). Marketing Ethics: An International Perspective. London, UK: Thomson Learning.

Shah, M. H., \& Xianhong, C. (2011). Rethinking Advertising Skepticism In China After West/Réfléchir L'effet De Scepticisme Face A La Publicité Scepticisme En Chine Après Les Occidentaux. Canadian Social Science, 7(1).

Shafiq, A., Haque, A., Kalthom, A. \& Jan, M. T., 2016. Beliefs about Islamic Advertising: An Exploratory Study in Malaysia. Journal of Islamic Marketiing, 8(3).
Advertising and Promotion (8 ed.). South-Western, Cengage Learning.

Singh, R., \& Kaur, P. (2014). Maternal Attitude towards TV Advertising in India. Management and Labour Studies, 39(2), 160-173.

Wilson, R. (2003). Foreword. In S. M. Hasanuzzaman, Islam and Business Ethics (pp. III-VI). London, UK: Institue of Islamic Banking and Insurance.

Zain, O. M. (2011). Readings in marketing: An Islamic Perspective. KL, Malaysia: IIUM Press.

Shimp, T. A. (2010). Integrated Marketing Communications in

Mustafa I Persepsi Demokrasi Indonesia di Arab Saudi Analisis Framming Berita Pemilihan Presiden Indonesia 2019 